\title{
Screening of CSDPs for AM Fungal Association from Arnala and Kalamb Beach Maharashtra
}

\author{
"Vishal R. Kamble, Bazegah K. Sayed and Nazia Qureshi \\ [Department of Botany, Bhavan's College Andheri (West), Mumbai 400 058, India
}

\begin{abstract}
Abstrtact: Fourteen coastal sand dune plants (CSDPs) belonging to nine families were screened for AM fungal association from Arnala and Kalamb beach which are disturbed by over increased anthropogenic activities. In present work the major mat-forming creeper, Ipomoea pes-caprae has showed association of five AM fungal species. It is also confirmed that, the plant members belonging to Asteraceae and Poaceae are dominant in tropical sand dunes.
\end{abstract}

Keywords: AM fungi, Coastal sand dune plants- CSDPs

\section{Introduction}

Most of the coastal areas in Maharashtra have lost natural vegetation from sandy beaches because of over increased human activities. The importance of arbuscular mycorrhizal (AM) fungi for the growth and succession of plant species in coastal sand dunes was first recognized in 1959 [27]. The coastal sand dunes exhibits favorable conditions for the association and development of AM fungi with plants as they are deficient in phosphorus [1]. AM fungi apparently are early arrivals in primary succession on sandy beaches and dunes [21]. The aggregation of sand grains and colonization of AM fungi with dune plants significantly stabilize the sand dunes [6], [22]. However, mycorrhiza and their mycosymbionts can be ignored only at the great risk of reaching unreal conclusion about ecosystem process [2], [7], [13].

Inventory on coastal sand dune AM fungi in India is very recent and has added significant data [10], [11], [23], [28], [29]. Regardless of their importance, the identity of AM fungal species in coastal sand dunes of Maharashtra is scantily known. In view of the fact that total length of Goa and Maharashtra coast is about 840 $\mathrm{km}$ of which $720 \mathrm{~km}$ belongs to the state of Maharashtra [26]. Nevertheless, in Maharashtra AM fungal association in costal sand dune plants (CSDPs) is fairly ignored with few exceptions [30]. Hence in present paper an attempt was made to screen AM fungal association from two sand dune beaches found in Thane District which are greatly disturbed by anthropogenic activity. Thane District of Maharashtra is possessing many natural habitats, valuable flora and fauna along with kilometers of beaches and sand dunes. Study area for present work comprises two beaches viz., Arnala and Kalamb situated at the geographical coordinates of $20^{\circ} 25^{\prime}$ 0" North, $73^{\circ} 5^{\prime} 00^{\prime \prime}$ East and $19^{\circ} 24^{\prime} 12^{\prime \prime}$ North, $72^{\circ} 45^{\prime} 42^{\prime \prime}$ respectively.

\subsection{AM fungal colonization}

\section{Material And Methods}

Roots and sand samples from the CSDPs rhizosphere were collected from both the study sites. At least four rhizosphere sand samples from the upper $20 \mathrm{~cm}$ layer were collected per each plant. In the laboratory, roots of all CSDPs species were screened for AM fungal colonization. Roots clearing and staining procedure [4], [19] was employed followed by microscopic observation for percentage colonization of AM fungi [14].

\subsection{AM fungal species identification}

The sand samples from each location were combined to obtain a single sample per location. The resulting rhizosphere sand was used to study AM fungal spore morphology. Spores present in the sand samples were extracted using the wet sieving and decanting method [8]. AM fungal spore identification was made after following the original descriptions [16] and also with internet published reference culture data bases http://invam.caf.wvu.edu.

\section{Results And Disscussion}

In present paper CSDPs for AM fungal association were screened from Arnala and Kalamb sand dunes which are representatives of some of the disturbed coastal sand dune ecosystems in Maharashtra. AM fungal colonization in total fourteen CSDPs viz., Cyperus rotundus L. (Cyperaceae), Eclipta prostrata (L.) L. (Asteraceae), Emilia zeylanica var. zeylanica C.B.Cl. (Asteraceae), Hedyotis spp. L. (Rubiaceae), Ipomoea pescaprae (L.) R. Br. (Convolvulaceae), Launaea procumbens (Roxb.) Rammaya and Rajgopal (Asteraceae), Martynia annua L. (Martyniaceae), Panicum L. spp 1 (Poaceae), Panicum L. spp 2 (Poaceae), Paspaldium punctatum (Burm. f.) A. Camus (Poaceae), Sesamum orientale L. (Pedaliaceae), Sesuvium portulacastrum (L.) 
L. (Aizoaceae), Sida rhombifolia L. (Malvaceae), Tridax procumbence L. (Asteraceae) was studied. It is now well established that in tropical sand dunes, plant species belonging to Asteraceae, Convolvulaceae, Fabaceae and Poaceae contribute towards the stabilization of coastal sand dunes [9], [15], [17], [21], [23]. Present study also confirms that, the plant members belonging to Asteraceae and Poaceae are dominant in tropical sand dunes. However, prevalence of some characteristic plant species belonging to the other families is frequently observed in disturbed sand dune sites which is a result of encroachment near beaches and faulty tourism practices.

The results obtained suggest that, all fourteen plant species belonging to nine different families were colonized by AM fungi (Table 1). CSDPs which exhibited 50-75\% AM fungal colonization are viz, I. pescaprae (Kalamb beach), Panicum spp 2, S. portulacastrum, S. rhombifolia, T. procumbens etc. Whereas, CSDPs viz., C. rotundus, E. prostrata, E. zeylanica var. zeylanica, Hedyotis spp., I. pes-caprae (Arnala beach), L. procumbens, M. annula, Panicum spp 1, P. punctatum, and S. orientale etc. showed more than $80 \%$ AM fungal colonization. In present investigation out of 14 plant species, seven showed more than $90 \%$ colonization which were: C. rotundus, E. zeylanica var. zeylanica, I. pes-caprae (Arnala beach), L. procumbens (Kalamb beach), $M$. апnиa, $P$. punctatum and $S$. orientale etc., amongst these seven plants exhibited highest percentage colonization which was absolutely $100 \%$ in L. procumbens (Kalamb beach) and S. orientale. In present paper, out of total nine families representing sand dune flora, Asteraceae and Poaceae were found dominating AM colonizers which agree with earlier reports [17],[18].

Recent study [30] showed that, I. pes- caprae and L. procumbens were having $99 \%$ and $84 \%$ colonization respectively from Revdanda coast of Maharashtra. In present investigation we have also obsereved close similarity in percentage colonization of I. pes- caprae (Arnala samples). However, I. pes- caprae samples from Kalamb site showed 63.63\%; whereas, Arnala and Kalamb samples of L. procumbens were encountered with $82.5 \%$ and $100 \%$ respectively. Thus to make any firm conclusion about variation or close similarity in colonization pattern of AM fungi with respect to CSDPs is very difficult. The most probable justification for these changes may be rapid exposure of these costal sand dune areas to human activities as well as certain abiotic factors probably sand erosion. Hence extension of research work is required to understand causes of variation in AM fungal pattern of colonization in coastal sand dunes.

All the component of AM fungi (vesicle, arbuscule and hyphae) were observed in six species viz. $C$. rotundus, I. pes-caprae, Panicum spp 2, P. punctatum (Kalamb site), Hedyotis spp. and T. procumbens (Arnala site). Whereas, remaining eight plant species showed presence of vesicles and hyphae while arbuscules were not developed in them. Thus in general, prevalence of arbuscules development in present study was poor in studied CSDPs exceptionally Hedyotis spp., Panicum spp 2 and Paspalidium punctatum. In present investigation it was also noticed that the pattern of vesicle formation was varied with changes in host plants.

Five species of AM fungal spores, viz., Acaulospora scrobiculata Trappe, Acaulospora spinosa Walker and Trappe, Gigaspora margarita Becker and Hall, Glomus intraradices Schenck and Smith and Sclerocystis sinuosa Gerdemann and Bakshi were recovered from rhizosphere of some CSDPs. Predominant encounter of all these AM fungal species in CSDPs was earlier reported from various regions excluding Maharashtra by different workers [9], [20] ,[28]. The Acaulospora scrobiculata was recorded more frequently (64\% plant species) followed by Glomus intraradices (34\% plant species) (Table 2). Out of 14 CSDPs except Ipomoea pes-caprae rest of the all plants showed either one or two AM fungal species in their rhizosphere.

Successful re-establishment of most effective plant communities is effective major for stabilization of disturbed coastal ecosystem [5], [29]. On the basis of ecological amplitude, mat-forming strand creepers are necessary for the fixation of mobile dunes and moving sand [25]. Sesuvium portulacastrum is a one of the matforming creeper which helps in the stabilization of dunes [24]. Earlier studies showed that, Sesuvium portulacastrum was neither colonized by AM fungi, nor did possess spores in the rhizosphere at the dunes of Hawaii [21] and Singapore [3]. However, in present investigation Sesuvium portulacastrum exhibited mycorrhizal colonization (53.73\%) and AM fungal spores viz., Acaulospora scrobiculata and Glomus intraradices were also recorded, which agree with results from the dunes of Gulf of Mexico and Australia [12],[31]. The major mat-forming creeper, Ipomoea pes- caprae in present work showed presence of diversity of AM fungal species. Earlier studies [23], [29] showed AM fungal association in a mat-forming creeper Launaea sarmentosa. In present paper, deep-rooted Launaea procumbens has showed excellent colonization in both the study sites. Thus, the mat-forming stand community like I. pes-caprae, $L$. procumbens and T. procumbens in present study sites showed mycorrhization and hence serves the purpose of sand dune stabilization in disturbed coastal ecosystem. 
Screening of CSDPs For AM Fungal Association From Arnala And Kalamb Beach Maharashtra

IV. TABLES

Table 2: AM fungal Association of CSDPs From Arnala and Kalamb Beach

\begin{tabular}{|c|c|c|c|c|c|c|}
\hline \multirow[t]{2}{*}{$\begin{array}{l}\text { Sr } \\
\text { No }\end{array}$} & \multirow[t]{2}{*}{ Costal sand dune Plants } & \multirow[t]{2}{*}{ *Site } & \multicolumn{3}{|c|}{$\begin{array}{c}\text { \#Occurrence intensity } \\
\text { AM fungi }\end{array}$} & \multirow{2}{*}{$\begin{array}{c}\text { AM fungal } \\
\text { colonization } \\
(\%)\end{array}$} \\
\hline & & & $\mathbf{V}$ & $\mathbf{A}$ & $\mathbf{H}$ & \\
\hline 1 & Cyperus rotundus L. (Fam: Cyperaceae) & $\mathrm{K}$ & ++++ & + & +++ & 90.56 \\
\hline 2 & Eclipta prostrata(L.)L.(Fam:Asteraceae) & $\mathrm{K}$ & ++++ & - & ++++ & 80.31 \\
\hline 3 & $\begin{array}{l}\text { Emilia zeylanica var. zeylanica C.B.Cl. } \\
\text { (Fam: Asteraceae) }\end{array}$ & $\mathrm{K}$ & ++++ & - & ++++ & 94 \\
\hline 4 & Hedyotis spp. L. (Fam: Rubiaceae) & Ar. & ++ & ++++ & ++++ & 87.5 \\
\hline \multirow[t]{2}{*}{5} & \multirow{2}{*}{$\begin{array}{l}\text { Ipomoea pes-caprae (L.) R. Br. } \\
\text { (Fam: Convolvulaceae) }\end{array}$} & Ar. & ++++ & - & + & 99 \\
\hline & & $\mathrm{K}$ & ++++ & + & ++ & 63.63 \\
\hline \multirow[t]{2}{*}{6} & \multirow{2}{*}{$\begin{array}{l}\text { Launaea procumbens (Roxb.) Rammaya } \\
\text { and Rajgopal (Fam: Asteraceae) }\end{array}$} & Ar. & ++++ & - & ++++ & 82.5 \\
\hline & & $\mathrm{K}$ & ++++ & - & ++++ & 100 \\
\hline 7 & Martynia annua L. (Fam: Martyniaceae) & Ar. & ++++ & - & ++++ & 92.5 \\
\hline 8 & Panicum L. spp 1 (Fam: Poaceae) & $\mathrm{K}$ & ++++ & - & ++ & 80.76 \\
\hline 9 & Panicum L. spp 2 (Fam: Poaceae) & $\mathrm{K}$ & + & ++++ & +++ & 70.37 \\
\hline 10 & $\begin{array}{l}\text { Paspaldium punctatum (Burm. f.) A. } \\
\text { Camus (Fam: Poaceae) }\end{array}$ & $\mathrm{K}$ & ++ & ++++ & ++ & 90.38 \\
\hline 11 & Sesamum orientale L.(Fam:Pedaliaceae) & Ar. & ++++ & - & ++++ & 100 \\
\hline 12 & $\begin{array}{l}\text { Sesuvium portulacastrum (L.) L. } \\
\text { (Fam: Aizoaceae) }\end{array}$ & $\mathrm{K}$ & +++ & - & +++ & 53.73 \\
\hline 13 & Sida rhombifolia L. (Fam: Malvaceae) & $\mathrm{K}$ & +++ & - & ++++ & 72.5 \\
\hline 14 & Tridax procumbensL. (Fam: Asteraceae) & Ar. & +++ & ++ & ++++ & 70.73 \\
\hline
\end{tabular}

[*Site: Ar-Arnala, K- Kalamb; ${ }^{\#}$ Occurrence intensity: (V) Vesicles, (A) Arbuscules, (H) Hyphae; (+) 1-25\%:

Poor; (++) 25-50\% : Moderate; (+++) 50-75\%: good; (++++) more than 75\%: Excellent; (-) = absent].

Table 2: CSDPs and their AM fungal species From Arnala and Kalamb Beach

\begin{tabular}{|c|c|c|c|c|c|c|c|}
\hline \multirow[t]{2}{*}{ Sr No. } & \multirow[t]{2}{*}{ Costal sand dune Plants } & \multirow{2}{*}{$\begin{array}{c}\text { *Study } \\
\text { site }\end{array}$} & \multicolumn{5}{|c|}{ AM fungi species occurrence } \\
\hline & & & Acs & Asp & Gma & Gin & Scs \\
\hline 1. & Cyperus rotundus $\mathrm{L}$. & $\mathrm{K}$ & + & + & - & - & - \\
\hline 2. & Eclipta prostrata (L.) L. & $\mathrm{K}$ & - & - & - & + & - \\
\hline 3. & $\begin{array}{l}\text { Emilia zeylanica var. zeylanica } \\
\text { C.B.Cl. }\end{array}$ & $\mathrm{K}$ & + & - & - & - & - \\
\hline 4. & Hedyotis spp. L. & A & - & + & - & - & + \\
\hline \multirow[t]{2}{*}{5.} & \multirow[t]{2}{*}{ Ipomoea pes-caprae (L.) R. Br. } & A & - & + & + & - & - \\
\hline & & $\mathrm{K}$ & + & - & + & + & + \\
\hline \multirow[t]{2}{*}{6.} & \multirow{2}{*}{$\begin{array}{l}\text { Launaeaprocumbens(Roxb.) } \\
\text { Rammaya and Rajgopal }\end{array}$} & $\mathrm{A}$ & + & - & - & + & - \\
\hline & & $\mathrm{K}$ & - & - & - & + & - \\
\hline 7. & Martynia annua $\mathrm{L}$. & A & + & - & - & - & + \\
\hline 8. & Panicum L. spp 1 & $\mathrm{~K}$ & + & - & - & - & - \\
\hline 9. & Panicum L. spp 2 & $\mathrm{~K}$ & + & - & - & - & - \\
\hline 10. & $\begin{array}{l}\text { Paspaldium punctatum (Burm. f.) } \\
\text { A. Camus }\end{array}$ & $\mathrm{K}$ & - & + & - & - & + \\
\hline 11. & Sesamum orientale L. & A & - & - & - & + & - \\
\hline 12. & Sesuvium portulacastrum (L.) L. & $\mathrm{K}$ & + & - & - & + & - \\
\hline 13. & Sida rhombifolia L. & $\mathrm{K}$ & - & - & - & + & - \\
\hline 14. & Tridax procumbens L. & $\mathrm{A}$ & + & - & + & - & - \\
\hline
\end{tabular}

[AM fungi species: Asc: Acaulospora scrobiculata, Asp: Acaulospora spinosa, Gma: Gigaspora margarita,

Gin: Glomus intraradices, Scs: Sclerocystis sinuosa] 


\section{Conclusion}

It is now well proved that, vegetation is an effective mean to reduce sand movements on beaches and dunes hence to restore these habitats. Over increased anthropogenic activities near the coastal area and on beaches is a serious concern of vegetation loss from sand dune area. Thus, planting CSDPs species in general, particularly mat forming creepers on the coastal sand dunes is becoming an important option to restore these habitats. The potential of AM fungal ability to establish mycorrhization in sand dunes can not be ignored at any cost. Thus to preserve disturbed costal sand dunes and beaches, proper use of AM fungal inoculums is becoming emerging need of time which can be certainly achieved through extension of such research programs. In present study, mat-forming strand creepers like I. pes-caprae, Launaea procumbens and Sesuvium portulacastrum have showed significant AM fungal association in study areas and thus have potential of fixation of mobile dunes, moving sands and in stabilization of sandy beaches disturbed by human pressure.

\section{Acknowledgment}

Thanks are due to Dr (Mrs) V. I. Katchi, Principal BCA (W), Mumbai, for providing Laboratory facilities.

\section{Reference}

[1] D.S. Ranwell, The Ecology of Salt Marshes and Sand Dunes, (Chapman and Hall, London, 1972).

[2] G.R. Safir, Ecophysiology of VA Mycorrhizal Plants. (CRC Press : Boca Raton, U.S.A., 1987).

[3] I. Louis, A mycorrhizal survey of plant species colonizing coastal reclaimed land in Singapore, Mycologia, 82: 1990, 772-778.

[4] J. M. Phillips, and D. S. Hayman, Improved procedure for clearing roots and staining parasitic and vesicular arbuscular mycorrhizal fungi for rapid assessment of infection, Trans. Br. Mycol. Soc., 55: 1970, $158-161$.

[5] J. Skujins and M.F. Allen, Use of mycorrhizae for land rehabilitation, Mircen Journal 2: 1986, 161-176.

[6] J.C. Sutton and B.R. Sheppard, Aggregation of sand dune soil by endomycorrhizal fungi, Canadian Journal of Botany 54: 1976, 326-333.

[7] J.M. Trappe and R. Fogel, Ecosytematic functions of mycorrhizae, in J.K. Marshell (Ed.), The below ground ecosystems, (Range Science Dept. Science series, Fort Collins Colorado State University, Co. 1977), $205-214$.

[8] J.W. Gerdemann, and T. H. Nicolson, Spores of mycorrhizal Endogone extracted from sand by wet sieving and decanting. Trans Br Mycol Soc 46: 1963, 235-244.

[9] K.R. Beena, A.B. Arun, N.S. Raviraja and K.R. Sridhar, Association of arbuscular mycorrhizal fungi with plants of coastal sand dunes of west coast of India. Tropical Ecology, 42(2): 2001, 213-222.

[10] K.R. Beena, N.S. Raviraja and K.R. Sridhar. Association of arbuscular mycorrhizal fungi with Launaea sarmentosa on maritime sand dunes of west coast of India. Kavaka 25: 1997, 53-60.

[11] K.R. Beena, N.S. Raviraja, A.B. Arun and K.R. Sridhar. Diversity of arbuscular mycorrhizal fungi on the coastal sand dunes of west coast of India. Current Science 79: 2000, 1459-1466.

[12] L. Corkidi and E. Rincon, Arbuscular mycorrhizae in a tropical sand dune ecosystem on the Gulf of Mexico I. Mycorrhizal statu s and inoculum potential along a successional gradient. Mycorrhiza 7: 1997, 9- 15.

[13] M. Brundrett, Mycorrhizas in natural ecosystems. Advances in Ecological Research 21: 1991, 131 - 171.

[14] M. Giovannetti, B. Mosse, An evaluation of techniques for measuring vesicular-arbuscular mycorrhizal infection in roots. New Phytologist, 87: 1980, 489-500.

[15] M.S. Devall, The biological flora of coastal dunes and wetlands. 2. Ipomoea pes-caprae (L.) Roth., Journal of Coastal Research 8: $1992,442-456$.

[16] N.C. Schenck, Y. Pérez,.Manual for the identification of VA mycorrhizal fungi. (University of Florida,Gainesville. 1990).

[17] P. Moreno-Casasola and I. Espejel. Classification and ordination of coastal sand dune vegetation along the Gulf and Caribbean Sea of Mexico, Vegetatio 66: 1986, 147-182.

[18] P. Moreno-Casasola, Patterns of plant species distribution on coastal dunes along the Gulf of Mexico. J Biogeogr, 15: 1988, 787806.

[19] R. E. Koske, J. N. Gemma, A modified procedure for staining roots to detect VA mycorrhizas. Mycol Res 92: 1989, 486-505.

[20] R.E. Koske and J.N. Gemma, Arbuscular mycorrhizal fungi in Hawaiian sand dunes: Islands of Kaua'i. Pacific Science 50: 1996, 36-45.

[21] R.E. Koske and J.N. Gemma, VA mycorrhizae in strand vegetation of Hawaii: Evidence for longdistance codispersal of plants and fungi, Am. J. Bot. 77: 1990, 466-474.

[22] R.E. Koske, and W.R. Polson. Are VA mycorrhizae required for sand dune stabilization? BioScience, 34: 1984, 420-424.

[23] S.S. Kulkarni, N.S. Raviraja and K.R. Sridhar, Arbuscular mycorrhizal fungi of tropical sand dunes of west coast of India. Journal of Coastal Research, 13: 1997, 931-936.

[24] T.A . Rao, and V.M. Meher-Homji, Strand plant communities of the Indian subcontinent, Proc. Indian Academy of Science (Plant Science), 94: 1985, 505-523.

[25] T.A. Rao, Management of Coastal Sandy Biomes in India. Proc. Seminar on Afforestation, Inst. Public Health Engineers, Calcutta, 1977.

[26] T.G. Jagtap, S. Naik and V. Ingale,. Assessment of Coastal Wetland Resources of Central West Coast, India, using LANDSAT Data, Journal of the Indian Society of Remote Sensing, 29(3), 2001, 140-150.

[27] T.H. Nicolson, Mycorrhiza in the Gramineae. I.Vesicular arbuscular endophytes with special reference to the external phase, Transactions of the British Mycological Society, 42: 1959, 132-145.

[28] V. Jaiswal and B.F. Rodrigues, Occurrence and distribution of arbuscular mycorrhizal fungi in coastal sand dune vegetation of Goa, Current Science, 80 (7), 2001, 826-827.

[29] V. Mohankumar, S. Ragupathy, C.B. Nirmala and A. Mahadevan, Distribution of vesicular arbuscular mycorrhizae (VAM) in the sandy beach soils of Madras coast. Current Science, 57: 1988, 367-368.

[30] V.R. Kamble, D.G. Agre, H. Rahate, Arbuscular Mycorrhizal in some medicinal plants found in sand dunes from Revdanda coast of Maharashtra, Proc. $1^{\text {st }}$ Nat Symp. of SAB on Innovative and Modern Technologies for Agricultural Productivity, Food security and Environment Management, Mangalore, India, 2011, 147-148.

[31] V.S. Logan, P.J. Clarke and W.G. Allaway, Mycorrhizas and root attributes of plants of coastal sand dunes of New South Wales, Australian Journal of Plant Physiology, 16: 1989, 141-146. 